\title{
Politics of Nostalgia and Populism: Evidence from Turkey
}

\author{
Ezgi Elçi* \\ Migration Research Center, Koç University, Istanbul, Turkey \\ ${ }^{\star}$ Corresponding author. E-mail: eelci14@ku.edu.tr
}

(Received 9 February 2020; revised 21 June 2020; accepted 17 September 2020; first published online 27 January 2021)

\begin{abstract}
This article scrutinizes the relationship between collective nostalgia and populism. Different populist figures utilize nostalgia by referring to their country's 'good old' glorious days and exploiting resentment of the elites and establishment. Populists instrumentalize nostalgia in order to create their populist heartland, which is a retrospectively constructed utopia based on an abandoned but undead past. Using two original datasets from Turkey, this study first analyzes whether collective nostalgia characterizes populist attitudes of the electorate. The results illustrate that collective nostalgia has a significantly positive relationship with populist attitudes even after controlling for various independent variables, including religiosity, partisanship, satisfaction with life and Euroscepticism. Secondly, the study tests whether nostalgic messages affect populist attitudes using an online survey experiment. The results indicate that Ottoman nostalgia helps increase populist attitudes. Kemalist nostalgia, however, has a weak direct effect on populist attitudes that disappears after controlling for party preference.
\end{abstract}

Keywords: populism; nostalgia; populist attitudes; survey analysis; survey experiment; Turkey

'I do not want to crumble under stress, quotas, and standards, but simply to work, as my father and grandfather did before me. I need the help of Marine', says a French fisherman in a presidential campaign ad for Marine Le Pen. We do not know whether fishing was easier before the quotas and standards implemented by the European Union (EU). Nor do we know whether the fisherman's father and grandfather simply worked without any challenges. What we do know is that a populist leader is promising to take power from EU elites and return it to the ordinary fishermen, as it was in the past.

There are multiple recent examples of populist leaders' nostalgic rhetoric. Donald Trump's slogan 'Make America Great Again' invokes the glorious past of the United States and American society, 'in which there was a clear order, non-whites and women "knew their place," and white working-class males made a decent living doing an honest day's work' (Mudde 2016). For Prime Minister Viktor Orban, 'Hungary hadn't been able to influence the fate of the Carpathian Basin since 1920 ... but now, thanks to the achievements of the last seven years, Hungary plays a central role in the region' (Kovács 2017), which recounts how the Treaty of Trianon diminished Hungary's power. Hungary's FIDESZ government declared 4 June the 'Day of National Cohesion' in 2010, the $90^{\text {th }}$ anniversary of the Treaty of Trianon, to commemorate the country's glorious past. The founding of the Trianon Museum in Várpalota and the revision of the educational curriculum are examples of other Orban-era commemoration practices (Petö 2017).

Similarly, Turkey's populist Justice and Development Party (Adalet ve Kalkınma Partisi, AKP) exploits nostalgic rhetoric to dominate the country's politics. The AKP governments frequently emphasize the glorious days of the Ottoman and Seljukian empires and assert that since the 
AKP has come to power, Turkey has changed for the better. According to the AKP and its supporters, a 'New Turkey' has risen from its ashes. The AKP has structured its narrative with slogans like 'Resurrection once again, rise once again' (Yeniden diriliş, yeniden yükseliş), which means that the country was glorious and strong in the past and will be so again.

Following these examples, this study questions the relationship between nostalgia and populism using both a representative survey and experimental datasets. Many populists around the world exploit nostalgia by referring to their country's glorious past. Populists frequently emphasize that the elites hijacked the people's will long ago, and they promise to return power to the people. According to this logic, back in the good old days corrupt elites were not powerful enough to abuse the authentic people. However, many regulations and institutions now hinder people's will. Populists exploit nostalgia to create their populist heartland, which corresponds to a retrospectively constructed utopia based on an abandoned but undead past (Bauman 2017; Taggart 2004).

So far, the literature on populism has covered qualitative case studies (for example, Mudde and Rovira Kaltwasser 2013; Taggart 1995; Weyland 2001), populist political communication (for example, Hameleers, Bos and de Vreese 2018; Jagers and Walgrave 2007; March 2017; Rooduijn and Pauwels 2011) and survey studies (for example, Akkerman, Mudde and Zaslove 2014; Rooduijn et al. 2017; Stanley 2011; Rooduijn, Van Der Brug and De Lange 2017; van Hauwaert and van Kessel 2018). However, there are few studies that test the psychological determinants of populism such as declinism (Elchardus and Spruyt 2016), emotions (Rico, Guinjoan and Anduiza 2017), personality traits (Bakker, Rooduijn and Schumacher 2016), societal pessimism (Steenvoorden and Harteveld 2018), nostalgic deprivation (Gest, Reny and Mayer 2018) and political identities (Melendez and Rovira Kaltwasser 2019). This study makes further contributions to the literature on the psychological factors that shape populist attitudes.

In the following section, I provide a theoretical background on populism, nostalgia and the link between the two. Next, I present the representative survey, items that were used to measure nostalgia and populism, along with the survey results. Then, I proceed to the survey experiment, a between-group design in which two groups received different types of nostalgic messaging in addition to a pure control group. The final section concludes the article.

\section{Theory}

\section{Populism}

This article follows the ideational approach to populism. According to Mudde (2007, 23), populism is 'a thin-centered ideology that considers society to be ultimately separated into two homogeneous and antagonistic groups, "the pure people" versus "the corrupt elite," and which argues that politics should be an expression of the volonté générale (general will) of the people'. More broadly, populism establishes an us vs. them identity by valorizing the people and its values while denigrating the elites. According to populists, the people's will is the cornerstone of politics; there is no higher authority.

Populism creates a duality in society based on a Manichean understanding of good vs. evil. According to Mudde (2017), populism differs from other ideologies because it is grounded in the Manichean duality on morality. According to populists, while the people are pure and authentic, elites are immoral and villain.

Many scholars agree that populism appears as a backlash to a sense of severe crisis (Rooduijn 2014; Taggart 2004) or discontent (Spruyt, Keppens and Van Droogenbroeck 2016). This sense of extreme crisis paves the way for raising concerns about the present conditions, which is a breeding ground for populism (Akkerman, Mudde and Zaslove 2014). Populists blame the establishment for the decline in the people's economic, political and living standards (Rooduijn, van der Brug and de Lange 2017). However, populism can also be generated by unsolved, long-lasting and cross-cutting political cleavages within a society. Somer and McCoy $(2019,8)$ define these 
cleavages as formative rifts that 'either emerged or could not be resolved during the formation of nation-states, or, sometimes during fundamental re-formulations of states such as during transitions from communism to capitalism, or authoritarian to democratic regimes'. Hence, while the sense of extreme crisis can be a recent change in a society, such as immigration for European countries, it can also be a secular-religious cleavage, as in Turkey (Aytaç and Elçi 2019; Somer 2019), or changes in gender and race relations, as in the United States (Duyvendak 2011; Mudde 2016). Populists aim to re-establish the present and future retrospectively by emphasizing the golden past of society to cope with contemporary challenges. Their goal is to return to a paradise lost in which life was better and more straightforward.

\section{Nostalgia}

The etymological roots of nostalgia come from Greek - a combination of nostos 'return home' and algia 'a painful condition' and can be roughly translated as 'a painful yearning to return home’ (Davis 1979, 1). Nostalgia first appeared as a problem of isolated monks who experienced extreme loneliness and melancholy due to their withdrawal from earthly life. The word nostalgia, however, was coined by Swiss medical student Johannes Hofer in 1688 when he observed the symptoms of soldiers fighting abroad (Boym 2001; Lowenthal 1985; Stauth and Turner 1988).

In line with Wildschut et al. $(2014,845)$, I define collective nostalgia as 'the nostalgic reverie that is contingent upon thinking of oneself in terms of a particular social identity or as a member of a particular group and concerns events or objects related to it'. According to Stauth and Turner $(1988,47)$, nostalgia is yearning for 'some golden age of heroic virtue, moral coherence and ethical certainty, a period in which there was no gap between virtue and action, between words and things, or between function and being'. They define four major components of nostalgia. First, 'there is the view of history as decline and loss, being a departure from some golden age of "homefulness". Second is the problem that there exists 'a sense of the loss of wholeness and moral certainty'. At this point, 'history is seen to be a collapse of values which had once provided the unity of social relations and personal experience'. The third is related to 'the loss of individual autonomy and the collapse of genuine social relationships'. Last but not least, nostalgia is 'the sense of a loss of simplicity, spontaneity, and authenticity' (Stauth and Turner 1988, 30-32; also see Bora and Onaran 2006 on this discussion).

'The nostalgic subject', for Tannock $(1995,454)$, 'turns to the past to find/construct sources of identity, agency, or community, that are felt to be lacking, blocked, subverted, or threatened in the present' because nostalgia is 'the search for continuity amid threats of discontinuity' (Davis 1979, 35). As a group-based emotion, nostalgia is related to social identity (Psaltis et al. 2017). According to social identity theory, identities are 'part of an individual's self-concept which derives from his knowledge of his membership of a group (or groups) together with the value and emotional significance attached to the membership' (Tajfel 1982, 2). The self-categorization of us vs. them is at the heart of social identity theory (Greene 1999). When absolute differences are salient between groups, people tend to perceive similarities of the in-group and exaggerate its differences from the out-group (Hornsey 2008). Nostalgia, or the way we remember our past, exacerbates in-group vs. out-group distinctions (Martinovic et al. 2018). Nostalgia also strengthens shared social identity and distinguishes the in-group from other groups (Brown and Humphreys 2002; Wildschut et al. 2014).

In the process of identity construction, history becomes a useful instrument for people to understand who they are, where they come from and where they should be going. The past emerges as a guideline during the constitution of group identity, its relationship with other groups, and as a defense mechanism for external threats (Davis 1979; Jetten and Hutchison 2011; Liu and Hilton 2005). In turn, nostalgia legitimizes the present action with references to the past (Gaston and Hilhorst 2018). According to Searle-White (2001, 49), group identity is not only its image of who it is now, but also who it has been in the past, and who its people 
hope it will be in the future'. References to past and nostalgic reveries help constitute people's identities and functions as an intermediary tool between memory and identity (Kalinina and Menke 2016). According to Smeekes $(2015,56)$, collective nostalgia triggers an in-group prototype 'as being part of a moral community based on shared past experiences' and out-group prejudice. The in-group and out-group stereotyping illustrates group boundaries between the authentic $u s$ and the alien them.

\section{Populism and Nostalgia}

Previous studies touched upon the relationship between nostalgia and populism in a relatively narrow sense. For example, Wiles $(1969,170)$ argues that populism dislikes 'the present and the immediate future' by seeking 'to mold the further future in accordance with its vision of the past'. For Betz and Johnson $(2004,324)$, right-wing populism is 'a backward-looking reactionary ideology, reflecting a deep sense of nostalgia for the good old days'. Furthermore, according to Sullivan (2017), the rise of populism is closely related to 'acute despair at the present moment and a memory of a previous golden age'. Populists aim to destroy the current status quo and 'return to the past in one emotionally cathartic revolt'. Populists constitute a new ideology of home - a vision of the lost homeland - which represents nostalgia for a reconstructed past and, in turn, provides a sense of security against the perceived loss of identity (Albertazzi and McDonnell 2008). Golden ages are crucial for populists because they provide sources of political legitimacy for the present, along with the rhetoric of authority and authenticity against troublesome changes, crises or decline (Elgenius and Rydgren 2019; Kenny 2017).

The golden age corresponds to the heartland in populist literature. Coined by Taggart (2004, 278), 'the heartland is a construction of the good life derived retrospectively from a romanticized conception of life as it has been lived'. It involves returning to the pre-lapsarian world, a Golden age before a catastrophic lapse or fall: in the post-lapsarian era, individuals feel lacking, deficient or oppressed (Tannock 1995). Populists aim to reach a retrotopia, which is based on 'visions located in the lost/stolen/abandoned but undead past, instead of being tied to the not-yet-unborn and so inexistent future' (Bauman 2017, 5).

The construction of the 'us vs. them' dichotomy is a function of cross-cutting conflicts in a given society (Barr 2009). During the construction of the antagonistic us and them, the heartland provides raw material where values are collected (Taggart 2004). There can be varieties of heartlands that no single theory can explain due to the unique characteristics of each society. Yet all such theories agree that society is divided along a single cleavage: the good, authentic people are separated from the corrupt, adversarial elites (Aslanidis 2020). Populists draw the borders of in-groups and out-groups by reconstructing the past and referring to the founding moment of the people (Cento Bull 2016). An escape to the heartland posits that 'a life has already been lived and so shown to be feasible. It assumes or asserts that there was a good life before the corruptions and distortions of the present' (Taggart 2004, 274). Building on these arguments, I expect that:

Hypothesis 1: The more nostalgic respondents are, the more populist attitudes they will express, because nostalgia creates a 'pure people vs. corrupt elites' duality.

HyPOTHESIS 2: Respondents in the nostalgia treatment groups should be more populist than those in the control group in the experimental setting.

\section{Populism And Nostalgia In Turkey}

In Turkey, what Şerif Mardin (1973) coined the center-periphery cleavage breeds both populism and nostalgia in Turkish politics (Aytaç and Elçi 2019; Elçi 2019). For Mardin (1973), the country's contemporary secularist vs. Islamist cleavage is a continuation of the socio-cultural and 
socio-economic duality between the ruling center and ruled periphery in the Ottoman Empire. While the former embraced secularism, Turkish nationalism, unitary state and state-supervised economy, the latter supports Islamism, conservatism, liberal economy and a decentralized state. According to the peripheral masses (which are composed of religiously, ethnically and regionally heterogeneous groups), the elites at the center (the foreign service, judiciary and military) have dominated Turkish politics and society as guardians of Kemalist values ${ }^{1}$ and the secular Turkish Republic (Kalaycıoglu 1994; Sunar 1990). Today, the center-periphery cleavage also overlaps with the left-right dimension in Turkish politics: the left appears as supportive of secularism and the right as the champion of Islamism (Çarkoğlu 2012; Çarkoğlu and Hinich 2006). The contemporary and significant representatives of the center vs. periphery cleavage are the Republican People's Party (Cumhuriyet Halk Partisi, CHP) and the AKP, respectively.

Ottoman nostalgia in Turkey constitutes a reaction to Kemalist modernization efforts and the cutting of ties to the Ottoman legacy in order to create a modern, secular nation-state (Karaveli 2010; Özyürek 2006). According to Bora (2011), the AKP inherited the Islamic nationalism of the National Outlook (Milli Görüş) tradition, ${ }^{2}$ which imagines Turkey as the potential leader of the Islamic world. Nostalgia for the Ottoman past, at this point, appears as an imperial and irredentist fantasy. Consequently, Ottoman nostalgia can be summarized as discourse and actions 'on the past intended to legitimize contemporary neoliberal and cultural policies by drawing on anachronistic reinterpretations and the glorification of the Ottoman past in Turkey' (Iğsız 2015, 327).

For right-wing politics, mainly Islamist and ultranationalist factions, the Ottoman Empire represents the zenith of the Turkish people's history (Bora 2011; Çetinsaya 2006). As a response to the Kemalist establishment's secular nationalism, political Islam aggrandizes the Ottoman past as a tool for the reconstruction of 'the Great Turkey' today. The collapse of the Ottoman Empire corresponds to the absence of home. Recep Tayyip Erdoğan has referred to verses of his favorite poet, Necip Fazıl Kisakürek, 'the people are odd and a pariah in his own homeland', because they no longer live under the authentic Ottoman rule but the secular, modern Turkish Republic (Yılmaz 2017). Ottoman nostalgia reflects resentment towards the Republican elites, as it serves as a tool for revealing, transforming and mobilizing the desires, ambitions and anger of the Islamist masses (Tokdoğan 2019).

Kemalist nostalgia is more recent: it appeared during the 1990s, an era of significant transformations in world politics. The collapse of the Soviet Union and dismemberment of Yugoslavia created a power vacuum in the region, which led to the rise of ethnic conflicts. It was also a period of growing religious politics, which coincided with the rise of political Islam and religious extremism. These transformations were echoed in Turkey with the rise of the Welfare Party (Refah Partisi), which represents a continuation of the Milli Görüş ideology. This was concurrent with the establishment of pro-Kurdish political parties, which eschewed the ideology of the Kurdistan Workers' Party (PKK) and the bloody terror campaign it waged in the 1990s (Bora 2013; Özyürek 2006).

In addition to the rise of identity and religious politics, the increasing demands of the EU, economic privatization, and increasing interactions with the International Monetary Fund and the World Bank have also challenged Kemalist ideology. In turn, many Kemalists began to share 'the memory of a strong, independent, self-sufficient state and its secularist modernization politics which dominated the public sphere through the past century' (Özyürek 2006, 2). In other words, when foundational principles were at stake, Kemalists started yearning for 'the childhood

\footnotetext{
${ }^{1}$ Kemalism is a quasi-ideology named after Turkey's founding leader, Mustafa Kemal Atatürk. According to Cizre-Sakallığlu and Çınar (2003, 310), Kemalism is 'a Westernizing/civilizing ideology whose incontrovertible maxims are secularism, understood as the separation of religion from political rule; a modern/Western identity and lifestyle; and the cultural homogeneity and territorial unity of the nation'.

${ }^{2}$ Milli Görüş is a political-Islamist ideology with strong anti-republican and pro-Ottoman characteristics (Çarkoğlu and Kalaycığlu 2009).
} 
of the nation when everything was pure, and citizens were gathered around the authority of their father' (Özyürek 2006, 16).

In short, Ottoman nostalgia appears to be an effective tool for channeling the resentment of peripheral groups towards centralist elites and the establishment in Turkey. However, Kemalist nostalgia emerged in reaction to the rise of political Islam and Islamist populism. Hence, I expect that:

Hyротнеsis 3: The effect of the Ottoman nostalgia treatment on populist attitudes should be greater than the Kemalist nostalgia stimulus in the experimental setting.

In summary, following the ideational approach, this study claims that populists aim to facilitate the moralistic separation between the pure people (us) and the corrupt elite (them). While constituting the boundaries of us vs. them, populists create an in-group vs. out-group identity. To this end, one of the primary tools that populists utilize is collective nostalgia. They aim to build the present and future retrospectively. Populists offer their constituencies a golden age a heartland where corruption, disruptions and enemies do not exist. The following two sections empirically analyze these arguments.

\section{Study 1: Survey Analysis}

This section tests the link between individuals' predisposition to nostalgia and populist attitudes (Hypothesis 1) using representative survey data $(n=1,954)$. I assume that after controlling for other independent variables, nostalgia should have a significantly positive impact on populist values.

The dependent variable is constructed from four survey items created by Hawkins, Riding and Mudde (2012). ${ }^{3}$ These four items aim to 'capture key elements of populism, especially a Manichaean view of politics, a notion of a reified popular will, and a belief in a conspiring elite' (Hawkins, Riding and Mudde 2012, 7). I aggregated the four items and created an index ranging from 0 (least agreement) to 100 (most agreement):

- Politics is ultimately a struggle between good and evil.

- The power of a few special interests prevents our country from making progress.

- The politicians in Parliament need to follow the will of the people.

- The people, and not the politicians, should make our most important policy decisions.

The primary independent variable is Nostalgia, which ranges from 0 (less agreement) to 100 (more agreement). It is constructed from four different survey items that seek to measure the importance of past values, past experiences, old tastes and the country's glorious past:

- Listening to new pieces of music, I miss the old days and those beautiful folk songs.

- We must not forget the values that we had in the past.

- I miss my country's good, old glorious days.

- We can get rid of the problems we experience today as 'the people' only by looking to our past.

Without anchoring to any particular period or group, these items aim to capture collective nostalgia, which can be different periods for the respondents. For example, as discussed in the

\footnotetext{
${ }^{3}$ The exploratory factor analyses (EFA) and confirmatory factor analyses (CFA) suggest that these items successfully construct the latent variables of Populism and Nostalgia. EFA indicates that there are two separate dimensions. CFA's fit indices are within the universally accepted cutoff levels (Hu and Bentler 1998). See the Appendix for detailed analyses.
} 
previous section, while CHP supporters could be nostalgic for the achievements of the Kemalist era, AKP supporters yearn for the glorious days of the Ottoman Empire.

I use three sets of independent variables to control for the relationship between nostalgia and populism. First, to connect the study to the broader populism literature and compare Turkey with previous studies on populism in different contexts, I used the support for EU membership, satisfaction with democracy, economic conditions, and life, and interpersonal trust questions. Secondly, to capture the effects of identity politics and the center-periphery cleavage in Turkey, I used variables such as Alevi, Kurdish and religiosity, where the cross-cutting cleavages in Turkish society occur. Lastly, I controlled for the effect of nostalgia with partisanship variables (see the Appendix for measurement of control variables). ${ }^{4}$

Before moving to the analysis, it is necessary to discuss the control variables and hypothesized relationships. According to Almond and Verba (1963[1989]), the norms of interpersonal relationships, general trust and confidence in the social environment are fundamental dynamics for establishing civic culture and democracy. Thus I expect that respondents who expressed positive interpersonal trust have less populist attitudes. Euroscepticism can be defined as 'the idea of contingent or qualified opposition, as well as incorporating outright and unqualified opposition to the process of European integration' (Taggart 1998, 366). It is a symptom of both radical right and left parties in Europe and its periphery (Rooduijn et al. 2017; Rooduijn, Van Der Brug and De Lange 2017). I expect to find a negative relationship between populist attitudes and support for EU membership. Finally, according to scholars who support the idea of populism as a response to a political crisis, subjective dissatisfaction with economic, social and political conditions leads to an increase in populist attitudes (Akkerman, Zaslove and Spruyt 2017; Bowler et al. 2017; van Hauwaert and van Kessel 2018). Thus I expect that the more dissatisfied respondents are with their lives in general, subjective economic conditions and democracy, the more populist attitudes they will have.

Religiosity plays a pivotal role in explaining the party preferences of the Turkish constituency and is a key independent variable for explaining the center-periphery cleavage. While more religious people have typically been on the periphery of politics, they have always distanced themselves from the Western-oriented secular politics of the establishment since the late Ottoman period. Thus I expect more religious respondents to display more populist attitudes. While the Alevi minority in Turkey tends to side with the center due to political Islam's Sunni-order-oriented policies (Çarkoğlu and Elçi 2018; Çarkoğlu 2005), Kurdish people are historically located as an anti-establishment constituency (Celep 2018). Thus I expect Alevi respondents to have less populist attitudes because they are more supportive of secularism. However, I predict that Kurdish respondents will have more populist attitudes because they are more critical of the Kemalist establishment. Finally, the AKP constituency, located on the periphery of Turkish society, should have more populist attitudes. The Peoples' Democratic Party (Halklarm Demokratik Partisi, HDP), as a radical democratic pro-Kurdish party, should also display more populist attitudes. I expect CHP and Nationalist Action Party (Milliyetçi Hareket Partisi, $\mathrm{MHP}$ ) voters to have less populist attitudes since they represent the status quo.

\footnotetext{
${ }^{4}$ The data used for analysis is a representative sample. Frekans Research (www.frekans.com.tr) conducted face-to-face interviews from 17 February to 2 April 2017. The sampling procedure starts with the classification of the Turkish Statistical Institute's (Türkiye İstatistik Kurumu, TUIK) twenty-six NUTS-2 regions. Data collection was carried out with a joint project. We distributed the target sample according to each region's share of the urban and rural population according to the current records of the Address-Based Population Registration System (Adrese Dayalı Nüfus Kayıt Sistemi). Next, we used TUIK's block data, with a block size of 400 residents. We aimed to reach twenty voters from each block without using any substitutions. We selected individuals in households, based on the reported target population of 18 years or older in each household, using a lottery method. Pollsters visited the same household up to three times until a successful interview was conducted. If for any reason that individual could not be reached, the household was dropped without applying a substitution.
} 
Finally, I include demographic variables - sex (female), age, education, income and urban residency. I also used age-squared to detect the nonlinear relationship of the age variable. Previous studies have not reported a significant relationship between populist attitudes and sex and age. However, some studies have found that populist attitudes are negatively correlated with urban living, higher education achievement and higher income levels in some contexts (Rooduijn et al. 2017; Spruyt, Keppens and Van Droogenbroeck 2016; van Hauwaert and van Kessel 2018; Rooduijn, Van Der Brug and De Lange 2017; Santana, Zagórski and Rama 2020) (Table 1).

\section{Results}

I created ten different models to control for the effect of collective nostalgia with party preferences and satisfaction with life, democracy and economic conditions. I controlled for the effects of satisfaction variables in separate models because once they enter the equation, they can affect party preferences due to a moderate correlation with party preference variables. It is not surprising that the AKP constituency is more satisfied with democracy, their lives and subjective economic conditions, since they voted for the winning party. Table 2 reports the standardized coefficients for comparing the magnitudes of the independent variables.

The results confirm the first hypothesis - that collective nostalgia positively correlates with populist attitudes in all models. A one-standard-deviation increase in nostalgia leads to a 0.26 -standard-deviation rise in populist attitudes, which is twice the size of other significant control variables. Collective nostalgia remains significantly positive even after controlling for other independent variables, including religiosity and party preference. Unfortunately, many independent variables did not reach statistical significance, which limits my ability to draw conclusions about the determinants of populist attitudes in Turkish politics.

In line with expectations, religiosity also has a significantly positive impact on populist attitudes. However, standardized coefficients indicate that the magnitude of nostalgia is even higher than religiosity. EU supporters have lower levels of populist attitudes, which is also the case in the broader populism literature. Urban dwellers appear less populist than other respondents, which tracks with the urban vs. rural divide in the populism literature. However, contrary to expectations, respondents who are more satisfied with their lives have more populist attitudes. Finally, only AKP voters emerge as a populist constituency among the other party supporters. In line with expectations, voting for the AKP and HDP has a positive relationship with populist attitudes, while preference for the CHP and MHP are negatively correlated. However, none of these relationships with populist attitudes reach conventional levels of statistical significance except for the AKP.

In summary, although the results indicate a positive relationship between nostalgia and populism, they do not provide any information about which type of nostalgia stimulates respondents' populist attitudes. The best way to overcome this shortcoming is an experimental analysis in which participants receive particular messages to stimulate their populist attitudes. The next section reports the results of such an experimental test.

\section{Study 2: Experimental Analysis}

This section applies experimental analysis to capture the causal link between nostalgia and populism. I created a between-group experimental design in which two groups received different types of nostalgic messages: Ottoman and Kemalist. The control group did not receive any stimulus.

\section{Data}

The experimental data were collected via convenience sampling. I recruited respondents through Facebook and Instagram advertisements using the Qualtrics survey tool. I conducted the survey 
Table 1. Descriptive statistics of survey analysis

\begin{tabular}{|c|c|c|c|c|c|}
\hline Variable & $\mathrm{N}$ & M & s.d. & Min & Max \\
\hline Populism index & 1,593 & 67.93 & 18.39 & 0 & 100 \\
\hline Nostalgia index & 1,724 & 72.66 & 20.17 & 0 & 100 \\
\hline Income & 1,724 & 3.09 & 1.33 & 1 & 6 \\
\hline Female & 1,954 & 0.50 & 0.50 & 0 & 1 \\
\hline Urban & 1,954 & 0.46 & 0.50 & 0 & 1 \\
\hline Education & 1,952 & 3.18 & 1.24 & 1 & 5 \\
\hline Age & 1,940 & 42.57 & 16.21 & 18 & 89 \\
\hline Religiosity & 1,791 & 7.12 & 2.06 & 0 & 10 \\
\hline Alevi & 1,954 & 0.15 & 0.36 & 0 & 1 \\
\hline Kurdish & 1,954 & 0.14 & 0.35 & 0 & 1 \\
\hline EU support & 1,954 & 0.03 & 0.94 & -1 & 1 \\
\hline Trust & 1,874 & 0.15 & 0.36 & 0 & 1 \\
\hline Satisfaction with life & 1,943 & 5.93 & 2.85 & 0 & 10 \\
\hline Satisfaction with democracy & 1,852 & 5.10 & 3.05 & 0 & 10 \\
\hline Satisfaction with economy & 1,898 & 4.13 & 2.59 & 0 & 10 \\
\hline AKP & 1,954 & 0.44 & 0.50 & 0 & 1 \\
\hline HDP & 1,954 & 0.03 & 0.18 & 0 & 1 \\
\hline $\mathrm{CHP}$ & 1,954 & 0.15 & 0.36 & 0 & 1 \\
\hline MHP & 1,954 & 0.08 & 0.27 & 0 & 1 \\
\hline
\end{tabular}

experiment between 23 and 24 June 2018. Participants did not receive any bonus or additional incentives.

I collected a total of 911 observations. After dropping respondents who failed attention checks, 803 observations remained. ${ }^{5}$ The Qualtrics survey tool applied randomization with no external intervention. Likelihood ratio tests from a multinomial logistic regression suggest that the randomization was successful $\left(\chi^{2}(10)=12.92, \mathrm{p}=0.23\right)$ (Table 3$)$.

\section{Experimental Design}

After informed consent was obtained, the first part of the survey asked respondents warm-up questions, such as their level of satisfaction with democracy, their lives and economic conditions. Participants responded to party preference questions before receiving treatments to avoid posttreatment bias (Montgomery, Nyhan and Torres 2018). Later, respondents were randomly assigned to one of three groups - the control group, the Ottoman nostalgia group and the Kemalist nostalgia group.

Next, I introduced experimental vignettes with the following message: 'Now you will be shown a text about the history of Turkey. Please read this text carefully and slowly. After reading, you will be asked some questions about the text.' Control group participants did not receive any notification and continued to answer the questions. The next button appeared after $3 \mathrm{~s}$ of receiving treatment messages. Respondents spent an average of $25.8 \mathrm{~s}$ on the stimulus (s.d. $=12.13$ ). Overall, the average response time was 16.41 minutes (s.d. $=18.34$ ).

The Ottoman and Kemalist nostalgia groups read texts that differed only in the underlined parts. The Ottoman nostalgia group received the following message:

This heavenly homeland is the trust of our ancestors. Since the Ottoman Empire, this people have always stood firmly against several external outbreaks, and their collaborators within us, that have played games with our country. Remember the glorious Ottoman! Remember Fatih, [and] Abdülhamit Han! When I miss those times, I wish I had lived in these good old days. ${ }^{6}$

\footnotetext{
${ }^{5}$ Attention checks are applied just after the treatment messages.

${ }^{6}$ Fatih refers to Mehmet the Conqueror (1432-1481), who was the seventh sultan of the Ottoman Empire. He conquered Istanbul and ended the Byzantine Empire. Abdülhamit Han (Sultan Abdülhamit II) (1842-1918) was the thirty-fourth sultan of the Ottoman Empire. He was dethroned following the 1908 Young Turk Revolution in 1909.
} 
Table 2. OLS regression analysis with beta coefficients

\begin{tabular}{|c|c|c|c|c|c|c|c|c|c|c|}
\hline DV: Populism & Model 1 & Model 2 & Model 3 & Model 4 & Model 5 & Model 6 & Model 7 & Model 8 & Model 9 & Model 10 \\
\hline Nostalgia & $0.266^{\star \star \star}$ & $0.268^{\star \star \star}$ & $0.266^{\star \star \star}$ & $0.265^{\star \star \star}$ & $0.266^{\star \star \star}$ & $0.265^{\star \star \star}$ & $0.266^{\star \star \star}$ & $0.264^{\star \star \star}$ & $0.264^{\star \star \star}$ & $0.264^{\star \star \star}$ \\
\hline Income & 0.047 & 0.052 & 0.049 & 0.046 & 0.047 & 0.030 & 0.033 & 0.029 & 0.030 & 0.030 \\
\hline Female & 0.030 & 0.033 & 0.031 & 0.025 & 0.029 & 0.019 & 0.020 & 0.017 & 0.016 & 0.018 \\
\hline Urban & $-0.083^{\star \star \star}$ & $-0.082^{\star \star \star}$ & $-0.083^{\star \star \star}$ & $-0.085^{\star \star \star}$ & $-0.083^{\star * \star}$ & $-0.053^{+}$ & $-0.054^{+}$ & -0.052 & $-0.055^{+}$ & -0.052 \\
\hline Education & 0.056 & $0.065^{+}$ & 0.059 & 0.054 & 0.055 & 0.056 & 0.059 & 0.053 & 0.054 & 0.055 \\
\hline Age & 0.154 & 0.125 & 0.155 & 0.175 & 0.161 & 0.189 & 0.172 & 0.190 & 0.200 & 0.201 \\
\hline $\mathrm{Age}^{2}$ & -0.213 & -0.182 & -0.211 & -0.238 & -0.220 & -0.242 & -0.225 & -0.247 & -0.256 & -0.253 \\
\hline Religiosity & $0.137^{\star \star \star}$ & $0.131^{\star \star \star}$ & $0.134^{\star \star \star}$ & $0.132^{\star \star \star}$ & $0.138^{\star \star \star}$ & $0.110^{\star \star \star}$ & $0.109^{\star \star \star}$ & $0.113^{\star \star \star}$ & $0.108^{\star \star \star}$ & $0.111^{\star \star \star}$ \\
\hline Alevi & -0.027 & -0.020 & -0.024 & -0.030 & -0.029 & -0.026 & -0.025 & -0.027 & -0.028 & -0.028 \\
\hline Kurdish & -0.048 & -0.044 & -0.050 & $-0.054^{+}$ & $-0.057^{+}$ & -0.040 & -0.039 & -0.038 & -0.044 & -0.054 \\
\hline Support for EU & $-0.066^{\star}$ & $-0.056^{+}$ & $-0.064^{\star}$ & $-0.067^{\star}$ & $-0.067^{\star}$ & $-0.060^{+}$ & $-0.057^{+}$ & $-0.061^{+}$ & $-0.061^{+}$ & $-0.059^{+}$ \\
\hline Trust & 0.021 & 0.011 & 0.019 & 0.020 & 0.021 & 0.008 & 0.006 & 0.009 & 0.008 & 0.007 \\
\hline Sat. w. Life & & & & & & $0.100^{\star}$ & $0.098^{\star}$ & $0.100^{*}$ & $0.099^{\star}$ & $0.100^{*}$ \\
\hline Sat. w. Dem. & & & & & & -0.004 & -0.014 & 0.000 & -0.007 & 0.001 \\
\hline Sat. with Econ. & & & & & & 0.033 & 0.029 & 0.036 & 0.032 & 0.035 \\
\hline AKP & & $0.064^{*}$ & & & & & 0.029 & & & \\
\hline $\mathrm{CHP}$ & & & -0.017 & & & & & 0.018 & & \\
\hline MHP & & & & $-0.049^{+}$ & & & & & -0.026 & \\
\hline HDP & & & & & 0.026 & & & & & 0.037 \\
\hline $\mathrm{N}$ & 1,273 & 1,273 & 1,273 & 1,273 & 1,273 & 1,208 & 1,208 & 1,208 & 1,208 & 1,208 \\
\hline $\mathrm{R}^{2}$ & 0.129 & 0.132 & 0.129 & 0.131 & 0.129 & 0.141 & 0.142 & 0.141 & 0.142 & 0.142 \\
\hline
\end{tabular}

Note: poststratification weights are applied. See the Appendix for the unstandardized coefficients and robust standard errors. ${ }^{+} p<0.1,{ }^{*} p<0.05,{ }^{\star \star} p<0.01,{ }^{\star \star \star} p<0.001$. 
Table 3. Sample characteristics of experimental data (mean of each category)

\begin{tabular}{lccrr}
\hline Variable & Control & Ottoman & Kemalist & All Obs. \\
\hline Age & 31.26 & 31.49 & 33.45 & 32.09 \\
Female & 0.23 & 0.23 & 0.26 & 0.24 \\
Education & 3.3 & 3.26 & 3.23 & 3.26 \\
AKP & 0.24 & 0.24 & 0.21 & 0.23 \\
CHP & 0.35 & 0.41 & 0.37 & 0.37 \\
\hline N & 281 & 246 & 276 & 803 \\
\hline
\end{tabular}

Note: age ranges between 18 and 71. Education ranges from 0 (elementary school graduate) to 5 (post-graduate).

The Kemalist nostalgia group received the following message:

This heavenly homeland is the trust of the founders of the Republic. Since the early years of the Republic, this people have always stood firmly against several external outbreaks, and their collaborators within us, that have played games with our country. Remember the glorious War of Independence! Remember İnönü, [and] Mustafa Kemal Atatürk! When I miss those times, I wish I had lived in these good old days.

All three groups then responded to nostalgia, identity and populism items, respectively. In the final part of the survey participants responded to demographic questions such as sex, age and education.

\section{Results}

I tested the effect of nostalgia treatments on populist attitudes by building a populism index with five items taken from Akkerman, Mudde and Zaslove (2014). ${ }^{8}$ I summed all items and built a scale between 0 and 100, where 100 indicates higher populist attitudes (Table 4).

According to Figure 1, respondents who received the Ottoman treatment are more populist than the control group participants, which confirms the second hypothesis. Although Kemalist nostalgia also has a positive impact on populist attitudes, its difference from the control group is not statistically significant. ${ }^{9}$ Lastly, the difference between Ottoman and Kemalist nostalgia is also nonsignificant, which rejects the third hypothesis.

Regression analysis highlights that the Ottoman nostalgia treatment has a positive impact on populist attitudes (Figure 2). However, the Kemalist nostalgia treatment has a barely significant positive effect on populism ( $\mathrm{p}=0.08$ ). To control for heterogeneous treatment effects, I also interacted the experimental treatments with party preference. While the effect of Ottoman nostalgia stays robust, the effect of Kemalist nostalgia disappears when party preference enters the equation, as in the interaction models. Finally, the effects of nostalgia treatments do not differ according to party preference. None of the interaction variables is statistically significant (see the Appendix for the results).

\footnotetext{
${ }^{7}$ İnönü refers to İsmet İnönü (1884-1973), who was the second president of Turkey after Atatürk and a hero of the Independence War. However, Islamist groups in Turkey broadly criticize him due to his staunch secularist rule.

${ }^{8}$ Populism items range from -2 to +2 . The item 'The politicians in the Parliament need to follow the will of the people' was dropped due to low variation and extreme negative skewness, which makes it impossible to manipulate with nostalgia messages. The item 'What people call compromise in politics is really just selling out on one's principles' was also dropped because it decreased Cronbach's alpha from 0.61 to 0.57 , which was already a poor score.

${ }^{9}$ The ANOVA result between experimental groups is $[F(2,785)=2.596, \mathrm{p}=0.08]$. The mean difference between the control and Ottoman nostalgia groups is $3.66(\mathrm{p}=0.08)$, and the mean difference between the control and Kemalist nostalgia groups is $2.96(\mathrm{p}=0.19)$.
} 
Table 4. Descriptive statistics and correlations of populism items (experimental data)

\begin{tabular}{|c|c|c|c|c|c|c|c|}
\hline Variable & $\mathrm{N}$ & M & s.d. & P1 & P2 & P3 & P4 \\
\hline $\begin{array}{l}\text { P1: The people, and not politicians, should make our most important policy } \\
\text { decisions. }\end{array}$ & 800 & 1.17 & 1.2 & 1.00 & 0.13 & 0.20 & 0.14 \\
\hline $\begin{array}{l}\text { P2: The political differences between the elite and the people are larger than } \\
\text { the differences among the people. }\end{array}$ & 797 & 0.96 & 1.2 & 0.13 & 1.00 & 0.20 & 0.30 \\
\hline P3: I would rather be represented by a citizen than by a specialized politician. & 802 & -0.31 & 1.53 & 0.20 & 0.20 & 1.00 & 0.28 \\
\hline P4: Politicians talk too much and take too little action. & 800 & 1.1 & 1.25 & 0.14 & 0.30 & 0.28 & 1.00 \\
\hline P5: Interest groups have too much influence over political decisions. & 799 & 1.23 & 1.08 & 0.20 & 0.29 & 0.26 & 0.46 \\
\hline Populism Index & 788 & 70.69 & 19.72 & & & & \\
\hline
\end{tabular}

\section{Conclusion And Discussion}

I conducted two different analyses using two different original datasets, and the results confirmed that nostalgia has a positive relationship with populism. The nostalgic electorate displays more populist attitudes at the mass level, and particular nostalgic messages increase populist attitudes in an experimental setting.

Populism has different characteristics in Turkey than in Western Europe in at least three ways. First, in Turkey it does not stem from anti-immigration sentiment (like in France or the Netherlands) or economic downturns (like Spain). Instead, the primary driver of populism in Turkey is the Islamist vs. secularist divide (Aytaç and Elçi 2019). Secondly, the right-wing populist AKP has been in power since 2002, resembling the long-tenured left-wing populist governments in Latin American countries such as Venezuela, Argentina and Ecuador (Selçuk 2016). Finally, although Turkey is not a member of the EU, it gained negotiating candidate status in 2005 and these negotiations are still in progress. While populism in Turkey also shares the antagonism of other European populist countries towards the elites in Brussels, successive AKP governments have kept the membership goal as an objective despite losing enthusiasm for full membership (Öniş and Kutlay 2019). Thus we should keep these similarities and differences in mind when generalizing the results.

This article demonstrates that nostalgia based on long-term cross-cutting cleavages breeds populist attitudes. Nostalgia offers a return to a lost paradise free of disruptions and corruption. It promotes an 'us vs. them' dichotomy in which the 'us' aims to protect its moral coherence and ethical certainty. In turn, nostalgia affects populist attitudes where the authentic people vs. immoral elites' dichotomy occurs.

Contrary to the assumption that populism is a reaction to a sense of crisis (Taggart 2004) or discontent (Spruyt, Keppens and Van Droogenbroeck 2016), as is valid in the cases of West European populism, this study illustrated that respondents who are satisfied with their lives also display populist attitudes (Aytaç, Çarkoğlu and Elçi 2020). This result also demonstrates that contemporary populism in Turkey does not stem from discontent, but rather from the formative rift on the secularist vs. Islamist division (Somer and McCoy 2019). It may also suggest that respondents internalize populist attitudes; even though they are satisfied with their lives, they may still be populist because their supported populist party is in power. We also see a similar pattern in Latin America, where more economically satisfied respondents display less support for measures that introduce checks and balances and protect civil liberties (Singer 2018).

Populism built on the formative rift argument can also be valid in the case of Hungary, which has been under the populist rule of Viktor Orban and his Fidesz party for a decade. Orban has constructed exclusionary rhetoric based on the trauma of the Treaty of Trianon, which led to the loss of two-thirds of the country's territory and half of its population in 1920. In December 2004, Hungary held a referendum on granting dual citizenship to ethnic Hungarians residing outside the country, which was depicted as a way of healing the scars of Trianon. While the leftist-liberal 


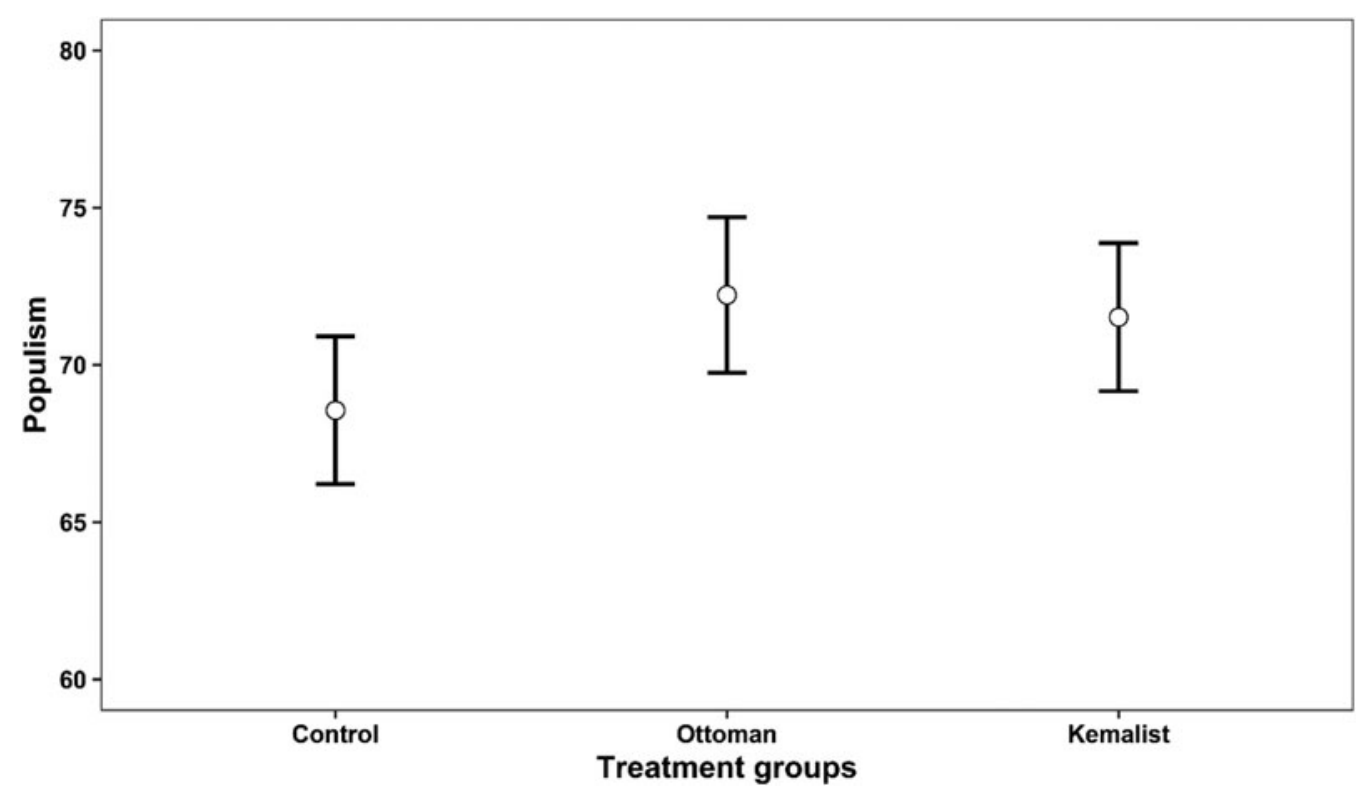

Figure 1. Mean plot of populism across treatment groups

Note: vertical lines indicate confidence intervals. Based on R package ggplot2 (Wickham 2016)

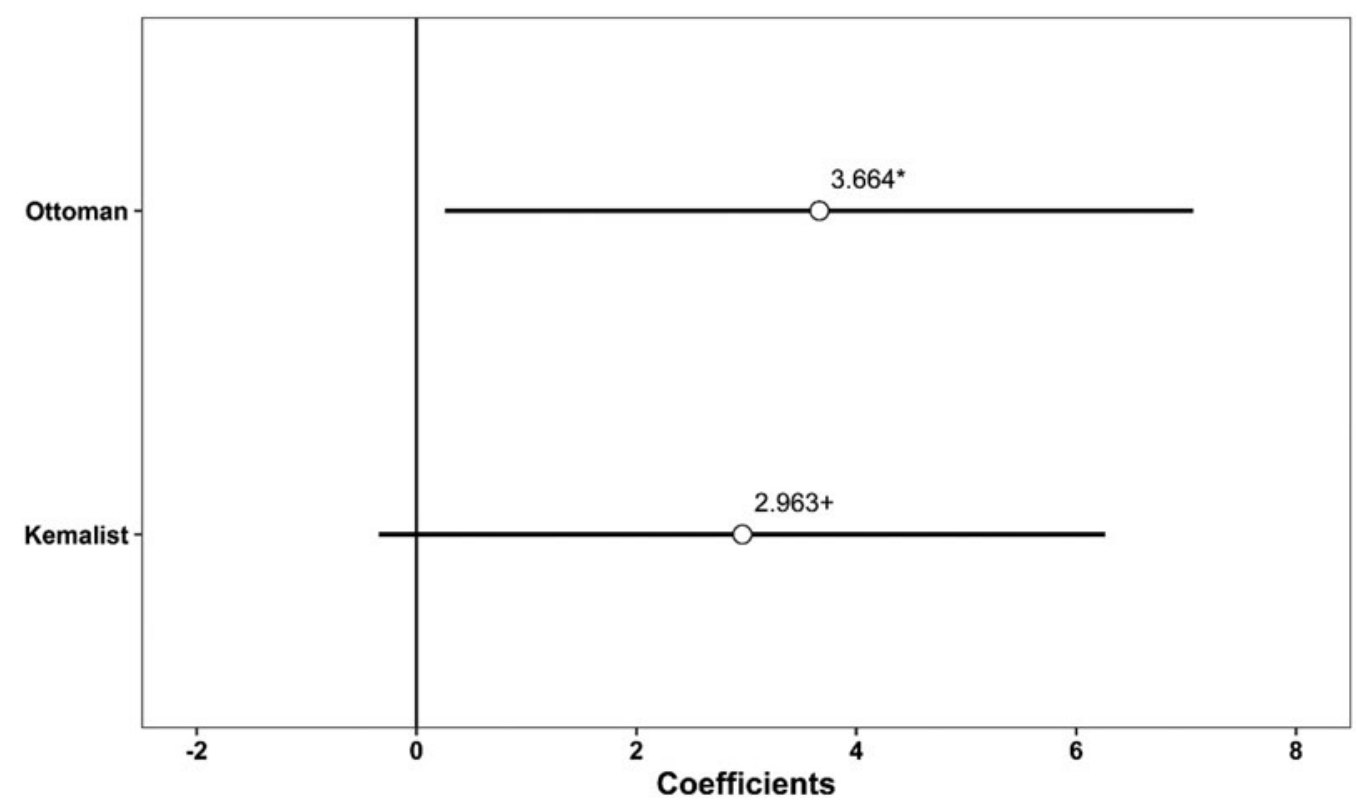

Figure 2. Regression analysis of average treatment effects on populist attitudes

Note: based on R package ggplot2 (Wickham 2016). See the Appendix for the regression table with standard errors. $+p<0.1,{ }^{\star} p<0.05$

coalition in power opposed the act, Fidesz and the far-right Jobbik party supported the bill. The bill was rejected due to low voter turnout (35 per cent), despite 51 per cent of the electorate voting in favor. The Orban government later granted citizenship and voting rights to ethnic Hungarians beyond the borders in 2010. Meanwhile, right-wing populism in Hungary has exploited the failed 
referendum to generate a duality in politics and society based on 'good' and 'bad' Hungarians (Inotai 2019; Pytlas 2013). In other words, similar to the commemoration practices of the collapse of the Ottoman Empire, Hungary still keeps pre-Trianon memories alive in daily politics along with public monuments, museums and speeches.

The experimental tests illustrate that Ottoman nostalgia has a significantly positive direct effect on populist attitudes. Mean plots and regression analyses show that respondents who received the Ottoman nostalgia treatment have significantly higher populist attitudes than control group respondents. Although Kemalist nostalgia also has a positive impact on populist attitudes, the result is barely significant. Nevertheless, once again, the results confirm the primary hypothesis: nostalgia has a significantly positive effect on populist attitudes.

Previous experimental studies scrutinizing the effects of collective nostalgia have focused on its mobilizing impact on in-group vs. out-group attitudes. For instance, Smeekes (2015) and Smeekes and Verkuyten (2015) illustrated that national nostalgia boosts in-group identification and protection as well as prejudice against non-Western immigrant groups in the Netherlands. Similarly, they demonstrated that autochthonic attitudes positively moderate the impact of national nostalgia on opposition to Muslim expressive rights. In addition to these examples, which take nativism as a dependent variable, this study also shows that collective nostalgia triggers populist attitudes in terms of generating a 'pure people vs. corrupt elites' intergroup cleavage. In other words, nostalgia generates an 'us' vs. 'them' duality in different societies in several different ways. However, when it taps into the moral distinction between the elites and the people, nostalgia increases populist attitudes.

While right-wing populists may use nostalgia more widely than left-wing populists, Bolivar nostalgia of Chavismo and the United Socialist Party of Venezuela is the most prominent counterexample to this argument (Roberts 2016). Another contemporary example is US Senator Bernie Sanders, who instrumentalizes nostalgia by emphasizing a period when the working class in the United States lived in better conditions than they do today (Gaston and Hilhorst 2018). In short, the content of nostalgia may change, but populists widely exploit it.

That being said, this study may shed light on contemporary populist politics in other countries. Multiple nostalgias in a given country may also lead to populism, which may in turn heighten polarization in politics and society. For example, Trump's nostalgia for an era of the so-called non-degenerated American values vs. Sanders' nostalgic reveries mentioned above can both catalyze polarization in the United States. In a similar vein, there are clashing nostalgias in the UK. Former Labour Party leader Jeremy Corbyn refers to the golden days of the welfare state system in the UK, while Prime Minister Boris Johnson's slogan of 'Take Back Control' is a typical example of nostalgia for the period before the UK joined the EU, which fueled the populist tendencies that paved the way for Brexit (Gaston and Hilhorst 2018; Kenny 2017).

The major shortcoming of this article is that it is a single case study. Other case studies can challenge the external validity of some of these assumptions. However, Ottoman and Kemalist nostalgias are both sui generis. In other words, it is not easy to test their effects in another context. Nevertheless, one can also argue that every country has its unique nostalgia for a specific period or periods. Very few common historical eras allow us to conduct a comparative experimental study, such as the era before the influx of immigrants to Europe, pre-Second World War or socialist rule. Still, although Ottoman and Kemalist nostalgias are unique to Turkey, this article suggests that future studies should focus on idiosyncratic nostalgias and their effects on populist attitudes in other contexts.

What is more, this study is conducted in a country where a populist party has been in power for almost two decades. Hence, I assume that 18 years is sufficient time to establish hegemony in all dimensions of the electorate's political, social and economic lives. Thus it is easy to manipulate populism for the AKP as the party in power. However, the results may be different in countries in which populist parties are in opposition and receive less media coverage. 
From a theoretical perspective, if one can manipulate populist attitudes by exploiting nostalgia in a country where the populist electorate is satisfied with its current conditions, we can understand why populist politicians are extremely inclined to instrumentalize nostalgia for their own ends. Nostalgia is a false memory, a whitewashed past, a glorious era that everyone can rally around. Therefore, the cost of exploiting it is low. Methodologically speaking, if one can manipulate populist attitudes in an extremely populist environment such as Turkey, where populism has already become an established ideology, the people's will has become extremely sacred, and the people represent the authentic and pure wisdom of politics, then it would be easier to conduct a similar analysis in other settings where populism has not penetrated all areas of political and social life.

Acknowledgements. I am grateful to Ali Çarkoğlu, S. Erdem Aytaç, Gülseli Baysu, Şener Aktürk, Cas Mudde, Ethan Busby and Ryan Carlin for their invaluable feedback and constructive criticisms. I also would like to thank three anonymous reviewers and editors for their extensive comments and suggestions. Earlier versions of this article were presented at the Midwest Political Science Association Annual Conference (Chicago, 2019), the Northeast Working Group Annual Conference (New York, 2019), the Political Studies Association Annual Conference (Cardiff, 2018), and Politicologenetmaal (Leiden, 2017). I would like to thank the discussants and participants of these events for their feedback.

Data availability statement. Replication data for this article can be found at Harvard Dataverse https://oi.org/10.7910/ DVN/29SA7P.

Supplementary material. Online appendices are available at https://doi.org/10.1017/S0007123420000666.

Financial support. The 2017 survey was funded by the Open Society Foundation, Turkey, and the 2018 survey was funded by Koç University, Graduate School of Social Sciences and Humanities.

Conflicts of interest. There are no conflicts of interest.

Ethical standards. The research was conducted in accordance with the protocols approved by the Koç University Ethics Committee.

\section{References}

Akkerman A, Mudde C and Zaslove A (2014) How populist are the people? Measuring populist attitudes in voters. Comparative Political Studies 47(9), 1324-1353.

Akkerman A, Zaslove A and Spruyt B (2017) 'We the people' or 'we the peoples'? A comparison of support for the populist radical right and populist radical left in the Netherlands. Swiss Political Science Review 23(4), 377-403.

Albertazzi D and McDonnell D (2008) Introduction: the sceptre and the spectre. In Albertazzi D and McDonnell D (eds), Twenty-first Century Populism. London: Palgrave Macmillan, pp. 1-11.

Almond GA and Verba S (1989) The Civic Culture: Political Attitudes and Democracy in Five Nations. Thousand Oaks, CA: Sage.

Aslanidis P (2020) The social psychology of populism. In Ron A and Nadesan M (eds), Mapping Populism: Approaches and Methods. London and New York: Routledge, pp. 166-175.

Aytaç SE, Çarkoğlu A and Elçi E (2020) Partisanship, elite messages, and support for populism in power. European Political Science Review. doi: 10.1017/S1755773920000314.

Aytaç SE and Elçi E (2019) Populism in Turkey. In Stockemer D (ed.), Populism Around the World. Cham: Springer, pp. 89-108.

Bakker BN, Rooduijn M and Schumacher G (2016) The psychological roots of populist voting: evidence from the United States, the Netherlands and Germany. European Journal of Political Research 55(2), 302-320.

Barr RR (2009) Populists, outsiders and anti-establishment politics. Party Politics 15(1), 29-48.

Bauman Z (2017) Retrotopia. Cambridge: Polity.

Betz HG and Johnson C (2004) Against the current-stemming the tide: the nostalgic ideology of the contemporary radical populist right. Journal of Political Ideologies 9(3), 311-327.

Bora T (2011) Nationalist discourses in Turkey. In Kadığlu A and Keyman F (eds), Symbiotic Antagonisms: Competing Nationalisms in Turkey. Salt Lake City: University of Utah Press, pp. 57-81.

Bora T (2013) AKP’ye tepki Atatürk nümayişinde birleşti [Reaction to the AKP converged in the Atatürk demonstration]. Radikal, 13 November. Available from http://www.radikal.com.tr/turkiye/akpye-tepki-ataturk-numayisinde-birlesti1160471/ (accessed 13 December 2020). 
Bora T and Onaran B (2006) Nostalji ve Muhafazakarlık [Nostalgia and conservatism]. In T Bora and M Gültekingil (eds), Modern Türkiye'de Siyasi Düşünce: Muhafazakarlık [Political Thought in Modern Turkey: Conservatism]. Istanbul: Iletişim, pp. 234-260.

Boym S (2001) The Future of Nostalgia. New York: Basic Books.

Bowler S et al. (2017) Right-wing populist party supporters: dissatisfied but not direct democrats. European Journal of Political Research 56(1), 70-91.

Brown AD and Humphreys M (2002) Nostalgia and the narrativization of identity: a Turkish case study. British Journal of Management 13(2), 141-159.

Çarkoğlu A (2005) Political preferences of the Turkish electorate: reflections of an Alevi-Sunni cleavage. Turkish Studies 6(2), 273-292.

Çarkoğlu A (2012) Voting behavior in Turkey. In Heper M and Sayarı S (eds), Handbook of Modern Turkey. London and New York: Routledge, pp. 160-170.

Çarkoğlu A and Elçi E (2018) Alevis in Turkey. In Rowe PS (ed.), Routledge Handbook of Minorities in the Middle East. London and New York: Routledge, pp. 212-224.

Çarkoğlu A and Hinich MJ (2006) A spatial analysis of Turkish party preferences. Electoral Studies 25(2), 369-392.

Çarkoğlu A and Kalaycıoğlu E (2009) The Rising Tide of Conservatism in Turkey. New York: Palgrave Macmillan.

Celep Ö (2018) The moderation of Turkey's Kurdish left: the Peoples' Democratic Party (HDP). Turkish Studies 19(5), 723-747.

Cento Bull A (2016) The role of memory in populist discourse: the case of the Italian Second Republic. Patterns of Prejudice 50(3), 213-231.

Çetinsaya G (2006) Cumhuriyet Türkiyesi'nde 'Osmanlıcllık' [Ottomanism' in the Republican Turkey]. In Bora T and Gültekingil M (eds), Modern Türkiye’de Siyasi Düşünce: Muhafazakarlık [Political Thought in Modern Turkey: Conservatism]. Istanbul: Iletişim, pp. 361-380.

Cizre-Sakallığlu Ü and Çınar M (2003) Turkey 2002: Kemalism, Islamism, and politics in the light of the February 28 process. The South Atlantic Quarterly 102(2), 309-332.

Davis F (1979) Yearning for Yesterday: A Sociology of Nostalgia. New York: Free Press.

Duyvendak JW (2011) The Politics of Home: Belonging and Nostalgia in Europe and the United States. New York: Palgrave Macmillan.

Elchardus M and Spruyt B (2016) Populism, persistent republicanism and declinism: an empirical analysis of populism as a thin ideology. Government and Opposition 51(01), 111-133.

Elçi E (2019) The rise of populism in Turkey: a content analysis. Southeast European and Black Sea Studies 19(3), 387-408.

Elçi E (2020), "Replication Data for: Politics of Nostalgia and Populism: Evidence from Turkey", https://doi.org/10.7910/ DVN/29SA7P, Harvard Dataverse, V1.

Elgenius G and Rydgren J (2019) Frames of nostalgia and belonging: the resurgence of ethno-nationalism in Sweden. European Societies 21(4), 583-602.

Gaston S and Hilhorst S (2018) At Home in One's Past: Nostalgia as a Cultural and Political Force in Britain, France and Germany. Mexico City: Demos.

Gest J, Reny T and Mayer J (2018) Roots of the radical right: nostalgic deprivation in the United States and Britain. Comparative Political Studies 51(13), 1694-1719.

Greene S (1999) Understanding party identification: a social identity approach. Political Psychology 20(2), 393-403.

Hameleers M, Bos L and de Vreese C (2018) Framing blame: toward a better understanding of the effects of populist communication on populist party preferences. Journal of Elections, Public Opinion and Parties 28(3), 380-398.

Hawkins KA, Riding S and Mudde C (2012) Measuring Populist Attitudes. Committee on Concepts and Methods. Working Paper Series No. 55, Mexico City: CIDE.

Hornsey MJ (2008) Social identity theory and self-categorization theory: a historical review. Social and Personality Psychology Compass 2(1), 204-222.

Hu LT and Bentler PM (1998) Fit indices in covariance structure modeling: sensitivity to underparameterized model misspecification. Psychological Methods 3(4), 424.

Iğsız A (2015) Palimpsests of multiculturalism and museumization of culture: Greco-Turkish population exchange museum as an Istanbul 2010 European Capital of Culture Project. Comparative Studies of South Asia, Africa and the Middle East 35(2), 324-345.

Inotai E (2019) How Hungary's 'Trianon Trauma' Inflames Identity Politics. Balkan Insight, 25 November. Available from https://balkaninsight.com/2019/11/25/how-hungarys-trianon-trauma-inflames-identity-politics/.

Jagers JAN and Walgrave S (2007) Populism as political communication style: an empirical study of political parties' discourse in Belgium. European Journal of Political Research 46(3), 319-345.

Jetten $\mathbf{J}$ and Hutchison $\mathbf{P}$ (2011) When groups have a lot to lose: historical continuity enhances resistance to a merger. European Journal of Social Psychology 41(3), 335-343.

Kalaycıŏlu E (1994) Elections and party preferences in Turkey: changes and continuities in the 1990s. Comparative Political Studies 27(3), 402-424. 
Kalinina E and Menke M (2016) Negotiating the past in hyperconnected memory cultures: post-soviet nostalgia and national identity in Russian online communities. International Journal of Media \& Cultural Politics 12(1), 59-74.

Karaveli HM (2010) An unfulfilled promise of enlightenment: Kemalism and its liberal critics. Turkish Studies 11(1), 85-102.

Kenny M (2017) Back to the populist future? Understanding nostalgia in contemporary ideological discourse. Journal of Political Ideologies 22(3), 256-273.

Kovacs Z (2017) PM Orbán: 'Hungary hasn't been this strong since Trianon'. About Hungary, 5 September. Available from http://abouthungary.hu/blog/pm-orban-hungary-hasnt-been-this-strong-since-trianon/ (accessed 4 December 2020).

Liu JH and Hilton DJ (2005) How the past weighs on the present: social representations of history and their role in identity politics. British Journal of Social Psychology 44(4), 537-556.

Lowenthal D (1985) The Past Is a Foreign Country. Cambridge: Cambridge University Press.

March L (2017) Left and right populism compared: the British case. The British Journal of Politics and International Relations 19(2), 282-303.

Mardin Ş (1973) Center-periphery relations: a key to Turkish politics? Daedalus 102(1), 169-190.

Martinovic B et al. (2018) Collective memory of a dissolved country: group-based nostalgia and guilt assignment as predictors of interethnic relations between diaspora groups from Former Yugoslavia. Journal of Social and Political Psychology 5(2), 588-607.

Meléndez C and Rovira Kaltwasser C (2019) Political identities: the missing link in the study of populism. Party Politics 25(4), 520-533.

Montgomery JM, Nyhan B and Torres M (2018) How conditioning on posttreatment variables can ruin your experiment and what to do about it. American Journal of Political Science 62(3), 760-775.

Mudde C (2017) An ideational approach. In Rovira Kaltwasser C, Taggart P, Espejo PO and Ostiguy P (eds), The Oxford Handbook of Populism. Oxford: Oxford University Press, pp. 27-47.

Mudde C (2016) Can We Stop the Politics of Nostalgia That Have Dominated 2016? Newsweek, 15 December. Available from http://www.newsweek.com/1950s-1930s-racism-us-europe-nostalgia-cas-mudde-531546 (accessed 4 December 2020).

Mudde C (2007) Populist Radical Right Parties in Europe. Cambridge: Cambridge University Press.

Mudde C and Rovira Kaltwasser C (2013) Exclusionary vs. inclusionary populism: comparing contemporary Europe and Latin America. Government and Opposition 48(2), 147-174.

Öniş Z and Kutlay M (2019) Global shifts and the limits of the EU's transformative power in the European periphery: Comparative perspectives from Hungary and Turkey. Government and Opposition 54(2), 226-253.

Özyürek E (2006) Nostalgia for the Modern: State Secularism and Everyday Politics in Turkey. Durham, NC and London: Duke University Press.

Pető A (2017) Revisionist histories, 'future memories': far-right memorialization practices in Hungary. European Politics and Society 18(1), 41-51.

Psaltis C et al. (2017) Social representations of the past in post-conflict societies: adherence to official historical narratives and distrust through heightened threats. In Psaltis C, Carretero M and Čehajić-Clancy S (eds), History Education and Conflict Transformation. New York: Palgrave Macmillan, pp. 97-122.

Pytlas B (2013) Radical-right narratives in Slovakia and Hungary: historical legacies, mythic overlaying and contemporary politics. Patterns of Prejudice 47(2), 162-183.

Roberts N (2016) When the boat comes in: myth, reification, and the changing face of Simón Bolívar in Venezuelan politics and culture. In MG Shanahan and AM Reyes (eds), Simon Bolivar: Travels and Transformations of a Cultural Icon. Gainesville: University Press of Florida, pp. 215-229.

Rico G, Guinjoan M and Anduiza E (2017) The emotional underpinnings of populism: how anger and fear affect populist attitudes. Swiss Political Science Review 23(4), 444-461.

Rooduijn M (2014) The nucleus of populism: in search of the lowest common denominator. Government and Opposition 49(4), 572-598.

Rooduijn M et al. (2017) Radical distinction: support for radical left and radical right parties in Europe. European Union Politics 18(4), 536-559.

Rooduijn M and Pauwels T (2011) Measuring populism: comparing two methods of content analysis. West European Politics 34(6), 1272-1283.

Rooduijn M, Van Der Brug W and De Lange SL (2017) Expressing or fueling discontent? The relationship between populist voting and political discontent. Electoral Studies 43, 32-40.

Santana A, Zagórski P and Rama J (2020) At odds with Europe: explaining populist radical right voting in Central and Eastern Europe. East European Politics 36(2), 288-309.

Searle-White J (2001) The Psychology of Nationalism. London and New York: Palgrave Macmillan.

Selçuk O (2016) Strong presidents and weak institutions: populism in Turkey, Venezuela and Ecuador. Southeast European and Black Sea Studies 16(4), 571-589.

Singer M (2018) Delegating away democracy: how good representation and policy successes can undermine democratic legitimacy. Comparative Political Studies 51(13), 1754-1788. 
Smeekes A (2015) National nostalgia: a group-based emotion that benefits the in-group but hampers intergroup relations. International Journal of Intercultural Relations 49, 54-67.

Smeekes A and Verkuyten M (2015) The presence of the past: identity continuity and group dynamics. European Review of Social Psychology 26(1), 162-202.

Somer M (2019) Turkey: the slippery slope from reformist to revolutionary polarization and democratic breakdown. The ANNALS of the American Academy of Political and Social Science 681(1), 42-61.

Somer M and McCoy J (2019) Transformations through polarizations and global threats to democracy. The ANNALS of the American Academy of Political and Social Science 681(1), 8-22.

Spruyt B, Keppens G and Van Droogenbroeck F (2016) Who supports populism and what attracts people to it? Political Research Quarterly 69(2), 335-346.

Stanley B (2011) Populism, nationalism, or national populism? An analysis of Slovak voting behaviour at the 2010 parliamentary election. Communist and Post-Communist Studies 44(4), 257-270.

Stauth G and Turner BS (1988) Nietzsche's Dance: Resentment, Reciprocity and Resistance in Social Life. Oxford: Blackwell.

Steenvoorden E and Harteveld E (2018) The appeal of nostalgia: the influence of societal pessimism on support for populist radical right parties. West European Politics 41(1), 28-52.

Sullivan A (2017) The Reactionary Temptation. New York Magazine. Available from http://nymag.com/daily/intelligencer/ 2017/04/andrew-sullivan-why-the-reactionary-right-must-be-taken-seriously.html (accessed 4 December 2020).

Sunar İ (1990) Populism and patronage: the Demokrat Party and its legacy in Turkey. Il Politico 55(4), 745-757.

Taggart P (1995) New populist parties in Western Europe. West European Politics 18(1), 34-51.

Taggart P (1998) A touchstone of dissent: Euroscepticism in contemporary Western European party systems. European Journal of Political Research 33(3), 363-388.

Taggart P (2004) Populism and representative politics in contemporary Europe. Journal of Political Ideologies 9(3), 269-288.

Tajfel H (1982) Introduction. In Tajfel H (ed.), Social Identity and Intergroup Relations. Cambridge: Cambridge University Press, pp. 1-11.

Tannock S (1995) Nostalgia critique. Cultural Studies 9(3), 453-464.

Tokdoğan N (2019) Yeni Osmanlıcılı: Hınç, Nostalji, Narsisizm [Neo-Ottomanism: Resentment, Nostalgia, Narcissism]. Istanbul: İletişim Yayınları.

Van Hauwaert SM and Van Kessel S (2018) Beyond protest and discontent: a cross-national analysis of the effect of populist attitudes and issue positions on populist party support. European Journal of Political Research 57(1), 68-92.

Weyland K (2001) Clarifying a contested concept: populism in the study of Latin American politics. Comparative Politics 34(1), 1-22.

Wickham H (2016) ggplot2: Elegant Graphics for Data Analysis. New York: Springer-Verlag.

Wildschut T et al. (2014) Collective nostalgia: a group-level emotion that confers unique benefits on the group. Journal of Personality and Social Psychology 107(5), 844-863.

Wiles P (1969) A syndrome, not a doctrine: some elementary theses on populism. In Ionescu G and Gellner E (eds), Populism: Its Meaning and National Characteristics. New York: Macmillan, pp. 166-179.

Yılmaz Z (2017) The AKP and the spirit of the 'new' Turkey: imagined victim, reactionary mood, and resentful sovereign. Turkish Studies 18(3), 482-513.

Cite this article: Elçi E (2022). Politics of Nostalgia and Populism: Evidence from Turkey. British Journal of Political Science 52, 697-714. https://doi.org/10.1017/S0007123420000666 